I NTER NATIONAL MONETARY FUND

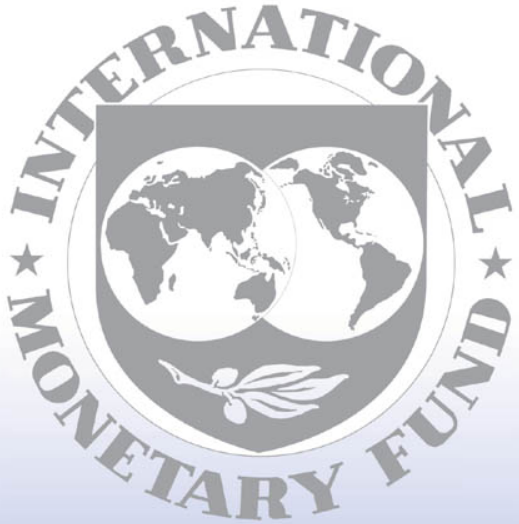

Staff

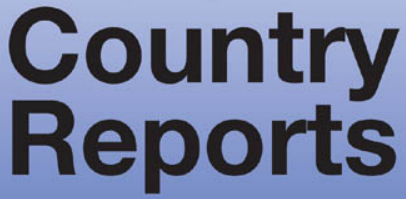




\section{Israel: Detailed Assessment of Observance of Basel Committee on Payments and Settlement Systems Core Principles for Systemically Important Payment Systems}

This paper was prepared based on the information available at the time it was completed in March 2012. The views expressed in this document are those of the staff team and do not necessarily reflect the views of the government of Israel or the Executive Board of the IMF.

The policy of publication of staff reports and other documents by the IMF allows for the deletion of market-sensitive information.

Copies of this report are available to the public from

International Monetary Fund $\bullet$ Publication Services

700 19th Street, N.W. • Washington, D.C. 20431

Telephone: (202) 623-7430 • Telefax: (202) 623-7201

E-mail: publications@imf.org • Internet: http://www.imf.org

\section{International Monetary Fund \\ Washington, D.C.}


FINANCIAL SECTOR ASSESSMENT PROGRAM UPDATE

\title{
ISRAEL
}

BASEL COMMITTEE ON PAYMENTS AND SETTLEMENT SYSTEMS CORE PRINCIPLES FOR SYSTEMICALLY IMPORTANT PAYMENT SYSTEMS

\section{DETAILED ASSESSMENT OF OBSERVANCE}

MARCH 2012

\author{
INTERNATIONAL MONETARY FUND \\ Monetary AND CAPITAL MARKETS DEPARTMENT
}


Glossary $\underline{3}$

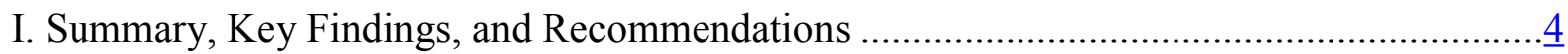

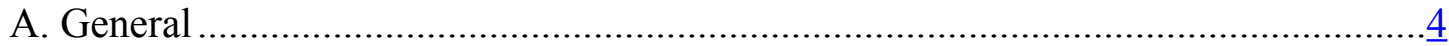

B. Information and Methodology Used for Assessment............................................. 4

C. Institutional and Macro-Prudential Setting, and Market Structure ........................... $\frac{5}{5}$

D. Prerequisites for Effective Payment Settlement Systems ……………………........

II. Assessment of the Core Principles and Central Bank Responsibilities..........................10

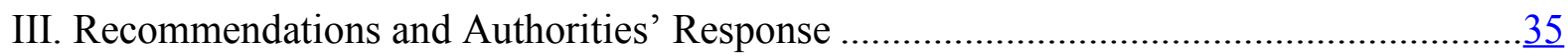

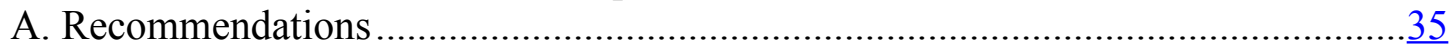

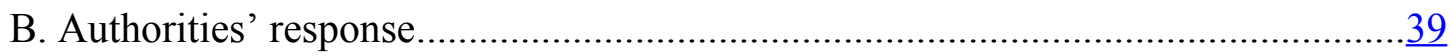

Tables

1. Volumes and Value of Payments in Israeli Payment Systems

2. Detailed Assessment of Observance of CPSS Core Principles for SIPS and Central Bank Responsibilities in Applying the CPs-Zahav

3. Summary Observance of CPSS Core Principles and Central Bank Responsibilities in Applying the CPs-Zahav $\underline{.35}$

4. Recommended Actions to Improve Observance of CPSS Core Principles and Central Bank Responsibilities in Applying the CPs-Zahav $\underline{38}$ 


\section{GLOSSARY}

$\begin{array}{ll}\text { ACH } & \text { Automatic Clearing House } \\ \text { BCA } & \text { Paper-Based Clearing House } \\ \text { BOI } & \text { Bank of Israel } \\ \text { CCMIS } & \text { Commissioner of Capital Markets, Insurance and Savings } \\ \text { CCP } & \text { Central counterparty } \\ \text { CLS } & \text { Foreign currency settlement system } \\ \text { CP } & \text { Core principle } \\ \text { CPSIPS } & \text { Core Principles for Systemically Important Payment Systems } \\ \text { CPSS } & \text { Committee on Payment and Settlement Systems } \\ \text { ELA } & \text { Emergency Liquidity Assistance } \\ \text { FSAP } & \text { Financial Sector Assessment Program } \\ \text { GAAP } & \text { Generally Accepted Accounting Principles } \\ \text { ICS } & \text { Intraday credit system } \\ \text { IFRS } & \text { International Financial Reporting Standards } \\ \text { ISA } & \text { Israeli Securities Authority } \\ \text { LSA } & \text { Loss-sharing arrangement } \\ \text { MOF } & \text { Ministry of Finance } \\ \text { MOU } & \text { Memorandum of Understanding } \\ \text { NIS } & \text { New Israeli Shekel } \\ \text { RTGS } & \text { Real Time Gross Settlement } \\ \text { SIPS } & \text { Systemically Important Payment Systems } \\ \text { TASE } & \text { Tel Aviv Stock Exchange } \\ \text { TASE-CH } & \text { Tel Aviv Stock Exchange Clearing House } \\ \text { TTC } & \text { Transaction types codes } \\ \text { UIS } & \text { The BOI's Unit for Information Security } \\ \text { Zahav } & \text { Hebrew acronym for real time credits and transfers } \\ & \end{array}$




\section{SUMmaRY, Key FindingS, AND RECOMMENDATIONS}

\section{A. General}

1. Following the previous Financial Sector Assessment Program (FSAP) report in 2001, a number of shortfalls from the Committee on Payments and Settlement Systems (CPSS) Core Principles for Systemically Important Payment Systems (CPSIPS) were identified and a number of recommendations made. This assessment considers the progress made toward implementing those recommendations and present compliance. The assessment was carried out of the single, central bank owned and operated high value payment system, Zahav (a Hebrew acronym for Real Time Credits and Transfers). However, the opportunity was taken to look at the payment and settlement systems, which make their final settlement in Zahav, from the point of view of a potential threat to the stability of Zahav (whether from participant liquidity, solvency, or operational problems).

\section{A significant improvement in the payments landscape was noted, with the high} value payment system now meeting most international standards. The underlying infrastructure, both contractual and operational, including contingency and risk management, is in place; and the system is stable and meets participants' needs. There is, nevertheless, room for improvement of the overall legal framework. Now that the initial phase of the introduction of Zahav is over, steps should be taken to create a superstructure of strategic planning, control, governance, and risk management, which will ensure the system can meet most eventualities, as befits this systemically important Israeli payment system. Most of the findings are in that vein.

3. The Zahav system was implemented in 2007 and the Payment Systems Law, which provides protection for the real time finality offered by Zahav, shortly afterward. The Payment Systems Law provides the legal underpinnings for central bank payment system oversight, which has been recognized in the new legislation for the Bank of Israel (BOI), which came into effect in 2010. As a result the setting up of a separate payment systems oversight function in the BOI, which was previously carried out within the ambit of banking supervision and subsequently in the Comptroller's Office, is still very much work in progress, and working to a project plan which will complete in 2013. As a result, the "Responsibilities of the Central Bank in Applying the Core Principles for SIPS" have not been formally assessed. Nevertheless, some observations are made and recommendations offered in this key area.

\section{B. Information and Methodology Used for Assessment}

4. This detailed assessment of observance report was prepared as part of the FSAP Update mission to Israel, which took place November 6-21, 2011. The Israeli Securities Settlement System, which is the Stock Exchange Clearing House (TASE-CH), has not been formally assessed as part of this FSAP; nor has it been subject to a self assessment. More specifically, the legal framework governing the issuance and holding of intermediated 
securities was not reviewed. Nevertheless, some ancillary investigations were carried out in order to better understand potential risks to Zahav stemming from it. This was true also for the Masav (direct debit and credit automatic clearing house (ACH) plus card company settlement) and the BOI owned and operated paper-based clearing house $(\mathrm{BCH})$. The assessment was carried out by Christopher Mann, an external technical expert in payments and settlement systems.

5. Because the oversight function is in the process of being set up, it was agreed that a self-assessment of the principles guiding Central Bank Responsibilities in applying the Core Principles for Systemically Important Payment Systems (CPSIPS) would not be offered and a full assessment would be premature. Nevertheless, where issues arose elsewhere that were relevant to the creation of that function they have been noted. The Authorities are encouraged to move forward with the setting up of oversight with all possible haste and to consider seeking a full assessment once it is complete, or is nearing completion.

6. The approach taken to the assessment of Zahav against the CPSS Core Principles was to review, in this specific context, an extensive list of documents provided by the BOI, which included a thorough and transparent self-assessment. Cooperation with the assessment was complete and open. Discussions were also held with participants of Zahav, including the foreign currency settlement system (CLS), which settles in Zahav the shekel side of foreign exchange trades settled by CLS.

7. The main laws supporting the Israeli legal framework were reviewed, in conjunction with IMF legal resources and discussions with legal counsels where appropriate. The mission members also reviewed the rules of Zahav, its participation agreements, pledge and other agreements, business continuity plans and risk assessments. The central bank website provides good summaries of a number of payment system aspects in particular, it provides access to annual reports on "Payment Systems in Israel," those for 2009 and 2010 in particular being reviewed. The "Red Book 2010-Israel's Payment and Settlement Systems" was also reviewed. Presentations were received from market participants and other bodies, such as the Israeli Securities Authority. All documents asked for were provided. The approach taken in the time available was to review the documents, raise in discussion issues arising from the review, follow up with discussions on issues arising from the discussions and a "cross-check" against third parties' views such as external users of the system.

\section{Institutional and Macro-Prudential Setting, and Market Structure}

8. The main financial institutions are banks and insurance companies; there is a large and active market in shares, corporate bonds, and government bonds; savers have available a variety of pension, provident, and mutual funds. At the time of the mission, the health of the financial sector was generally satisfactory. 
9. The BOI supervises banks and is responsible for payments system oversight. The Israel Securities Authority (ISA) oversees the securities sector, while the Commissioner of Capital Markets, Insurance, and Savings (CCMIS) at the Ministry of Finance (MOF) mainly deals with the insurance and pension sector. The Tel Aviv Stock Exchange (TASE) has some supervisory responsibilities for its members.

\section{Zahav is the only real time gross settlement (RTGS) system in Israel. Four} payment systems participate in the Zahav system: the Stock Exchange Clearing Houses (the Maof Clearinghouse and the Securities Clearinghouse), the Bank Settlement Center (Masav) (an $\mathrm{ACH}$ ), the Paper Clearinghouse (BCH) and the CLS system. In addition to the BOI, the Postal Company, and CLS Banks, and the 15 commercial banks are direct participants, either as online or offline participants. ${ }^{1}$ In 2010, Zahav handled over a quarter of a million payments to an aggregate value of NIS 75 billion (compared to a GDP of over NIS 800 billion), which represents about 87 percent of total amount of activity in the system (Table 1). The BOI's monetary and foreign exchange operations (and for its customers, largely public sector) have come to dominate the picture, accounting for 87 percent of total value owing to the very relative high value of their transactions. The activity in the Zahav system is characterized by a high degree of concentration, since the inter-bank activity of the two largest participants in the system is about 57 percent of the total value of payments. The inter-bank activity of the five largest participants in the system is about 78 percent of the total value of payments in Zahav (excluding BOI activities). The clearing houses' volume of trade in the Zahav system in 2010 stood at about 7 percent of the total amount of settlement in the system. The multilateral net settlement of the automated credits and debits in Masav, the checks in the check clearing, and securities and derivatives settlement in TASE-CH accounted in 2010 for the same value of settlement as all interbank transactions. In conclusion, the safe and robust operation of Zahav is crucial to the overall stability of the system.

\footnotetext{
${ }^{1}$ Compared with online participants, offline participants lack the SWIFT Fin Y-Copy infrastructure and so submit and receive their payments via an on-line member. In all other respects, including the settlement account, access to intraday liquidity and the ability to manage their payments they are as any other direct participant. The three offline members are Dexia Public Finance Israel, Bank Yahav for Government Employees Ltd, and Arab Israel Bank Ltd.
} 
Table 1: Israel: Volumes and Value of Payments in Israeli Payment Systems

\begin{tabular}{|c|c|c|c|c|c|c|c|c|c|c|c|c|}
\hline & \multicolumn{9}{|c|}{ Zahav } & \multirow{2}{*}{$\begin{array}{c}\text { MASAV } \\
\text { Debits } \\
\text { and } \\
\text { Credits }\end{array}$} & \multirow{2}{*}{$\begin{array}{c}\text { BCH } \\
\text { (Checks } \\
\text { and Other } \\
\text { Paper) }\end{array}$} & \multirow{2}{*}{$\begin{array}{l}\text { TASE-CH } \\
\text { Gross } \\
\text { Payment } \\
\text { Value) }\end{array}$} \\
\hline & Interbank & $\begin{array}{c}\text { (Percent } \\
\text { Total } \\
\text { Zahav) }\end{array}$ & CLS & $\begin{array}{c}\text { (Percent } \\
\text { Total } \\
\text { Zahav) }\end{array}$ & $\begin{array}{l}\text { Clearing } \\
\text { Houses (1) }\end{array}$ & $\begin{array}{c}\text { (Percent } \\
\text { Total } \\
\text { Zahav) }\end{array}$ & $\mathrm{BOI}$ & $\begin{array}{c}\text { (Percent } \\
\text { Total } \\
\text { Zahav) }\end{array}$ & Total & & & \\
\hline Value & \multicolumn{12}{|c|}{ (NIS millions) } \\
\hline 2008 & 5,894 & 27 & 508 & 2 & 7,506 & 34 & 7,966 & 36 & 21,875 & 1,739 & 826 & 1,658 \\
\hline 2009 & 3,809 & 6 & 933 & 1 & 4,831 & 8 & 52,731 & 85 & 62,304 & 1,779 & 787 & 1,595 \\
\hline 2010 & 4,575 & 6 & 1,097 & 1 & 4,294 & 6 & 65,818 & 87 & 75,784 & 1,958 & 858 & 1,586 \\
\hline $\begin{array}{l}\text { Growth '09-'10 } \\
\text { (in percent) }\end{array}$ & 20 & $\ldots$ & 18 & $\ldots$ & -11 & $\ldots$ & 25 & $\ldots$ & 22 & 10 & 9 & -1 \\
\hline \multicolumn{13}{|l|}{ Volume ('000) } \\
\hline 2008 & 186 & 86 & 8 & 4 & 9 & 4 & 14 & 6 & 218 & 254,211 & 135,833 & $\ldots$ \\
\hline 2009 & 156 & 80 & 10 & 5 & 9 & 5 & 21 & 11 & 198 & 260,622 & 125,006 & 94,925 \\
\hline 2010 & 218 & 83 & 11 & 4 & 11 & 4 & 22 & 8 & 261 & 276,542 & 125,039 & 106,292 \\
\hline $\begin{array}{l}\text { Growth '09-'10 } \\
\text { (in percent) }\end{array}$ & 40 & ... & 3 & $\ldots$ & 14 & $\ldots$ & 2 & $\ldots$ & 32 & 6 & 0 & 12 \\
\hline Average value & \multicolumn{12}{|c|}{ (NIS thousands) } \\
\hline 2008 & 31,688 & $\ldots$ & 63,500 & $\ldots$ & 834,000 & $\ldots$ & 569,000 & $\ldots$ & 100,802 & 7 & 6 & $\ldots$ \\
\hline 2009 & 24,417 & $\ldots$ & 93,300 & $\ldots$ & 536,778 & $\ldots$ & $2,511,000$ & $\ldots$ & 317,878 & 7 & 6 & 17 \\
\hline 2010 & 20,986 & $\ldots$ & 99,727 & $\ldots$ & 390,364 & $\ldots$ & $2,991,727$ & $\ldots$ & 289,252 & 7 & 7 & 15 \\
\hline $\begin{array}{l}\text { Growth '09-'10 } \\
\text { (in percent) }\end{array}$ & -14 & $\ldots$ & 7 & $\ldots$ & -27 & $\ldots$ & 19 & $\ldots$ & -9 & 0 & 17 & -12 \\
\hline
\end{tabular}

Source: BOI, TASE-CH, and staff estimates.

Value of nominal GDP in 2010: NIS 814 billion.

1. In 2010, TASE-CH accounted for NIS 579 billion in multilateral net settlement, NIS 137 billion of individual gross transactions settled directly and NIS 2.8 trillion of ICL transactions; MASAV accounted for NIS 566 billion and BCH NIS 229 billion. 
11. The jump in the volume of interbank settlements in Zahav by $\mathbf{4 0}$ percent in $\mathbf{2 0 1 0}$ compared with only small growth in the volumes of checks and credits can be attributed to several factors: the awareness campaign for Zahav approved by the Bank of Israel, as well as to the reduction in the maximum amount which can be paid in the Masav multilateral net settlement payment systems to NIS 1 million (there is no lower limit on payments in Zahav and no upper limit in the Paper Based Clearing House) and, finally, the significant reduction in fees charged by banks to their customers for the use of Zahav. Much of the 40 percent growth in volume in interbank Zahav payments was in the lower value range, leading to a significant fall in the average value of interbank payments, which now stands at NIS 21 million compared with NIS 32 million at the start of the system.

\section{Legal and institutional framework}

12. In 2010, a new law came into effect for the BOI ("the BOI Law"). Among other changes, it followed up the requirements on the central bank enshrined in the 2008 Payments Systems Law. The 2008 Payment Systems Law established the oversight function of the BOI and provided for the finality and irrevocability rules applicable to payment systems; the new BOI Law requires, more widely, the BOI to "regulate the payment and settlement systems in the economy, with the goal of ensuring their efficiency and stability, including in accordance with the Payment Systems Law." The Payments System Law specifically excludes the multilateral net payment system embedded in the Stock Exchange Clearing House and includes an indirect amendment to the Securities Law in consequence of which the ISA has responsibility for the oversight of TASE-CH according to principles which reflect those in the Payment Systems Law. There is a MOU between the BOI and the ISA covering coordination between them.

13. Together with the creation of the Zahav system, as part of the reform in the payment and settlement systems, the BOI also introduced a series of other changes and improvements into the existing payments systems, in order to bring them into line with accepted international standards. The principal changes, according to the BOI's Annual Report on Payment Systems, were:

- Cancellation of retroactive recording of transactions in the banks' accounts so that balances in the banks' accounts are final. ${ }^{2}$

- Extending the business day from 15:00 to 18:30, so that transactions can be performed in the Zahav system in the afternoons and evenings as well.

\footnotetext{
${ }^{2}$ Before the advent of Zahav, the outcome of batch settlement in the BOI's General Ledger was known only with a day's delay, so that banks had to back value payments in their own books and any interbank loans needed to ensure settlement.
} 
- Creation of an interbank arrangement to handle the failure of one of the participants in the multilateral Masav clearing or check clearing house to ensure that Clearing House payments are settled by the Zahav System houses by the end of the day at the latest. ${ }^{3}$

- Implementing the improvements in the check clearance process, including mandatory electronic settlement for all banks, cancellation of retroactive check clearing, check imaging and transfer of files between banks, and initiation of a law for check truncation. In 2009 a memorandum of law "Electronic Check Clearing, 5768-2008" was published.

- Implementing the improvements in the Masav $[\mathrm{ACH}]$ clearing process, including a change in the order of operations so that sending of the files to the banks (clearing) takes place only after settlement in the Zahav system, cancellation of retroactive settlement of returns and the creation of two settlement windows during the day (morning and evening).

- The TASE Clearing Houses settles on a Model 3 DvP basis (multilateral net settlement of cash and multilateral net settlement of the associated securities if, and only, the cash leg settles). It has been taking steps to re-engineer the settlement process so that the time gap between these two related settlement events occur within no more than 15 minutes of each other. Equities will move to this timetable shortly.

- In addition, work has commenced on deciding on the future of check clearing.

\section{There is a National Payments Council, where are represented the various stakeholders in the payments industry.}

\section{Prerequisites for Effective Payment Settlement Systems}

\section{Israel has a solid institutional framework supporting the conduct of macro-} economic policies. The Israeli legal framework for the financial sector is comprehensive and regularly updated. The auditing and accounting rules applicable to financial institutions generally comply with international standards. The judicial system is well-developed. The legal and institutional framework is in place for the resolution of bankruptcy cases, but needs development in respect of special resolutions frameworks for failing or failed banks. The corporate governance of financial institutions in Israel is governed by the Companies Law and the Securities Law. In addition, sectoral legislation has been introduced to regulate the operation of each financial sector, such as banks (the Banking Licensing Law and the Banking Ordinance), mutual funds (Joint Investment Trust Law), provident funds (Provident Funds), and pension funds (Pension Counseling and Pension Market Law).

\footnotetext{
${ }^{3}$ But not due to the default of that member: the rules of this arrangements specifically rule out its use in the event or even the likely event of a default, making it more of a liquidity mechanism to facilitate settlement in the event of problems other than of a solvency nature.
} 


\section{Assessment of the Core Principles and Central Bank Responsibilities}

\section{In the following assessment a core principle (CP) is considered observed} whenever all assessment criteria are generally met without any significant deficiencies. A CP is considered broadly observed whenever only minor shortcomings are observed, which do not raise major concerns and when corrective actions to achieve full observance with the $\mathrm{CP}$ are scheduled and realistically achievable within a prescribed period of time. A $\mathrm{CP}$ Is considered partly observed whenever the shortcomings are sufficient to raise doubts about the system's ability to achieve observance within a reasonable time frame. A CP is considered non-observed whenever major shortcomings are found in observing the assessment criteria. A CP is considered not applicable whenever it does not apply given the structural, legal and institutional conditions.

\section{Note that a full assessment of central bank responsibilities and transparency of} payment system oversight was not part of the scope of this assessment. Only summary comments have been made about the first and none about the second. The development of the Oversight Function is in its early days in a project to be completed in 2013.

\section{Table 2 Israel: Detailed Assessment of Observance of CPSS Core Principles for SIPS and Central Bank Responsibilities in Applying the CPs-Zahav}

\section{CP I-The system should have a well-founded legal basis under all relevant jurisdictions \\ Description \\ The legal framework governing the Israeli Payment System consists of (a) the Payment Systems Law 2008, (b) the BOI Law, 2010 and (c) the Securities Law.}

\section{Payment Systems Law, 2008}

The Payment Systems Law 2008 specifically governs the payment systems and is not applicable to the Stock Exchange Clearing Houses (namely the Stock Exchange, the Maof Clearing House and TASE-CH), with exception regarding the authority to require information according to Article 17 of the Law..

It sets up, for these payment systems, (a) the oversight regime, (b) the finality and irrevocability rules, as well as (c) specific provisions on collateral arrangements entered into between the BOI and system's participants in connection with the extension of intraday credit.

\section{a) Oversight regime}

The Payment System Law 2008 provides that, if the payment system's activity is vital to the general payment framework within the economy and there is concern that the improper, inefficient or unreliable activity of the system might affect the payment framework within the economy, then the Governor may declare it a "controlled" system. If, in addition, the system's activity is material to the monetary and financial stability in Israel and for maintaining stability, and would, in the Governor's view, 
benefit from the protections afforded by those sections in the Act in respect of finality of payments in the system and the operation of insolvency law, the Governor may declare it a "designated" controlled system.

In both cases, in making his determination, the Governor may take into account the estimated overall amount of the payment orders which will be received or executed in the system, during an ordinary day;

the estimated number of payment orders which will be received or executed in the system, during an ordinary day; the number of system participants;

whether such system is linked to another controlled system or to the Stock Exchange Clearing House; and

the extent of the influence the system has upon Israeli currency.

A controlled or designated controlled system is required:

to have rules ensuring the system's stability, efficiency and proper functioning, including rules concerning the continued participation in the system of a participant against which liquidation proceedings are being conducted, and concerning the means to enforce said rules

to operate the system in a manner ensuring its stability, efficiency and proper functioning;

to have the existence of means for the management, prevention and mitigation of risks which might exist or which in fact exist in the system; and

to have the existence of back-up arrangements in the system in the event of emergency.

Controlled or designated controlled systems and designated controlled systems are subject to the oversight of the BOI with a view to ensuring the overall reliability, accessibility, efficiency and security of these services. For these purposes, the BOI may require that such systems provide them with any document or information. If need be, the $\mathrm{BO}$ may require such systems to introduce changes in their rules or processes. Such changes may even be introduced in the designated controlled systems by the BOI itself.

It is noteworthy that as in Israel the implementation of laws of parliament is always entrusted to the relevant Minister; under Article 21 of the Payment Systems Law, the power to implement this law has been entrusted to the Minister of Finance.

Where it is proved to the Governor's satisfaction that another authority, which has powers similar to those vested in the Governor and the BOI pursuant to this Law, is in fact carrying out due control of a controlled system and of the system operator, the Governor may exempt such system, the system operator and the system participants from the provisions of the Payment Systems Law, in whole or in part, but not, if they are "designated" systems, from the protections afforded for finality and the operation of insolvency law. This power has been exercised in the case of CLS.

By means of an indirect amendment to the Securities Law in the Payments System Law, the ISA is given responsibility for overseeing the payment system embedded in the Stock Exchange Clearing House according to principles, which reflect those in the Payment Systems Law. There is a MOU between the BOI and the ISA covering 
coordination between them.

By virtue of its exclusion from the scope of the Payment System Law in para 2(a), (with exception regarding the authority to require information according to Article 17 of the Law), the payment system embedded in TASE cannot benefit from the protections in paras. 14 and 15 of the Law concerning finality and the operation of insolvency law.

To date, declarations have been made only in respect of Zahav and CLS, both of which have been declared designated controlled systems. (Work is in train to make declarations in respect of Masav and $\mathrm{BCH}$. They thus do not yet benefit from the protection of the Payment Systems Law. There is a discussion taking place about whether they should be declared "designated" systems or just controlled systems, partly in respect of the point of final settlement and concerning "returns" in both systems. ${ }^{4}$

Attention needs to be given to the use of the General Ledger as an alternative in the event the Zahav application is unusable (which will involve both prime and back up sites) to ensure intraday finality and protection from the zero hour rule. It is thought its use is not covered by the protections available to Zahav by virtue of its designation. A solution is being explored under which the General Ledger is declared a designated, controlled system. An alternative approach would be to define the General Ledger as an integral part of the designated controlled Zahav system in the Zahav Rules, in respect of its use in a contingency situation. A further issue is that the architecture of the General Ledger is such, that the order in which orders are received is not recorded, and it is not possible to know participants' balances in the course of processing, so finality is not assured, The $\mathrm{ACH}$ is also an alternative means of payment in a Zahav application outage, which has yet to benefit from the protections of the Payment Systems Law.

The rules of the Zahav system, which are part of the system of agreements between the system participants and the $\mathrm{BOI}$, provide the $\mathrm{BOI}$ with means of enforcing the system rules. They include:

Blocking a participant from using the system: this can be done in a variety of situations as a result of, among other things, a significant violation of the system rules, recurring non-fulfillment in multilateral settlement or a serious and protracted failure of the participant's communication infrastructure.

\footnotetext{
${ }^{4}$ Checks which a bank decides not to pay and ACH payments which cannot be applied by the recipient bank need to be returned. This is normally a process which takes place after multilateral net settlement has taken place and settled in an RTGS system with finality. Monies are returned and settled in a subsequent multilateral net settlement, rather than the original multilateral net settlement being unwound or finality of it held up for the days it takes for monies to be returned. What the arrangements are for returns and recourse between banks and their customers are a private matter to them and not normally considered a part of the Payment System's Rules. The arrangements according to which a credit stemming from a check is final between the bank and its customer are set in the legislation
} 
Imposition of a financial sanction: the $\mathrm{BOI}$ has the right to impose a financial sanction on a system participant for the violation of one of the system rules that has a significant influence on the efficiency and safety of the system and for recurring non-fulfillments of obligations as part of multilateral settlement.

Zahav itself comprises Rules and Procedures, a Participation Agreement and an Intraday Credit System (ICS) agreement, which participants must sign. The rules define, among other things, the arrangements for the activity of the system both in normal and emergency periods; criteria for membership in the system, for cancelling membership, for suspending a participant from activity in the system; arrangements related to default by a system participant; and the process of settling messages in the system, including the means for the management of transactions in the system. In addition, the rules include arrangements of a legal nature relating to issues which include, among others: the liquidation process of a participant, notification to participants of exceptional events in the system. In addition, the rules provide information with regard to fees for use of the system.

Added to the Zahav rules are appendixes that constitute an integral part of the rules. The appendixes include detailed and in-depth information on various issues related to the activity of the system in both normal and emergency periods, including: the required details of the system participants, a list of contact people among the participants, the hours of the system's operation and the clearance windows for multilateral payment orders, a list of the system's transaction type codes (TTC), forms for requesting the implementation of changes from the operator of the system and various arrangements related to the activity of the participants in various emergency situations.

There are two types of agreements for participation in the Zahav system: The first is between the BOI and the settlement participant who has an account in the Zahav system (banks and the Postal Bank) while the second is an agreement between the $\mathrm{BOI}$ and each of the payment systems participating in the system, i.e., payment systems that send multilateral payment orders to the Zahav system for settlement.

The agreement for participation in the Zahav system includes clauses, which relate to various issues, including (i) the agreement of the participant to abide by the rules of the Zahav system; (ii) granting of permission to the BOI to debit the participants' account as part of settlement in the system; (iii) a compensation arrangement; (iv) a netting arrangement; $(\mathrm{v})$ waiver of confidentiality for a represented participant;

(vi) the law that applies to the agreement; and (vii) judicial authority.

There are further agreements between the $\mathrm{BO}$ and the banks participating in the system with regard to encumbrance and guaranteed bonds, which provide collateral to the $\mathrm{BOI}$. The BOI provides intraday credit to the participants in the Zahav system against various types of collateral, including, among others, securities deposited in the BOI account at the TASE-CH Ltd, cash in shekel and foreign currency on deposit at the $\mathrm{BOI}$ and certain foreign securities. The arrangements for delivering securities to the BOl's account in TASE-CH, for TASE-CH to inform the central bank and for the central bank to provide credit in Zahav is covered by the bespoke Intraday ICS system, which is in turn the subject of an agreement between the parties. The agreement deals with a variety of issues including: the operational side of the ICS 
system (such as the procedure for the depositing of collateral by participants in the $\mathrm{BOI}$ account at the Clearinghouse and the procedure for withdrawing collateral with the approval of the $\mathrm{BOI}$ ), defining the rights and obligations of each side in the agreement and the manner in which various legal issues are to be resolved.

The Stock Exchange Clearinghouses Ltd., which includes the Stock Exchange Clearinghouse and the Maof Clearinghouse, operates as the Central Counterparty (CCP). Under the BOI Law, the BOI has the power to assist the Clearing House in the case of the failure of a member and in order to maintain the continuity of settlement and trading on the Stock Exchange.

The rules of the Zahav system, which constitute the main component of the system's legal basis, are distributed electronically and securely to the system participants, i.e., the commercial banks in Israel and the payment systems participating in the Zahav system (the Stock Exchange Clearinghouses, the Paper Clearinghouse and Masav). Immediately following an update of the rules, which occurs at least once a year, an updated copy is distributed to the system participants.

The legal basis for the Zahav system, which includes laws, directives, agreements and rules, has not yet been tested in the courts.

In accordance with the Ordinance of Evidence, certain printouts of an electronic record are accepted evidence in the courts in Israel. Zahav system printouts are within the aforesaid accepted evidence Since the Zahav system enables the printing of an output that provides evidence of the settling of a payment order, this output constitutes acceptable evidence in the courts.

The laws regarding contracts in Israel recognize and protect agreements made between parties. Accordingly, all laws relating to the Zahav system, as well as agreements signed between the various sides in the context of the system's activity, can be enforced.

b) Irrevocability and finality

Articles 14 and 15 of the Payment Systems Law organize the finality and irrevocability of payment orders entered into payment systems as follows("finality" and "irrevocability" seem to be used synonymously in the law, at least in the available English translation):

Article 14 establishes first the principle of irrevocability. It also stipulates that rules adopted by a designated controlled system on finality of transfer orders, that shall be published in the Official Gazette, shall be binding and enforceable vis-à-vis the system's participants. So far, the 2 designated controlled systems - Zahav and CLS - have opted for a rule according to which finality occurs when the relevant (cash and securities) accounts are credited and/or debited.

Article 15 - which consists of 7 paragraphs - addresses the impact of a liquidation order granted in respect of a participant in a designated controlled system, when such participant has entered transfer orders into the system, be it before, on the day of or after the liquidation order was issued. The legal protection of Article 15 of the 
Payment Systems Law is specified in relation only to "liquidation orders" (according to the translation from the Hebrew text).

Under Article 15 (a), the liquidator must notify the liquidation order to the BOI that informs the system's operator that informs, in its turn, the system's participants. Under Article 15(h), the notification provides that such notification is deemed to have been received on the date it was sent, unless the system operator proves that it did not receive such notification or that it received it later.

Article 15(b) neutralizes the usual claw-back rules that are contained in Section 268 of the Companies Ordinance [new version, 5743-1983]. It stipulates, nevertheless, that a court may declare the underlying transaction null and void if it was made in bad faith, without consideration or in breach of rights of other creditors.

Article $15(\mathrm{~g})$ stipulates the validity and enforceability of netting arrangement between the system's operator and the participant, upon issuing a liquidation order and subject to the system rules.

Articles 15 (c), (d), (e) and (f) specifically address the scenarios of transfer orders entered into the system by the participant, just prior to the issuance of the liquidation order. If the transfer order has been entered into the system and has been carried out prior to the issuance of the liquidation order, this will remain valid. If a transfer order has been entered into the system but has not yet been carried out at the moment the system's operator is informed of the issuance of the liquidation, such system's operator shall have up to one hour after the receipt of the notification to carry out (or let the system process) the pending transfer order, provided the full payment in respect of the pending transfer order had been transferred to the credit of the system operator or to the credit of the other participant.

As currently drafted, the Payment System Law captures only the issuance of liquidation order against domestic participants to the designated controlled systems. One participant is the branch of an overseas bank and another is CLS, the international payment settlement system. No legal opinions are sought from nondomestic participants to identify any legal provisions under the law of their country of origin which may negatively impact the domestic system. . If a private international law rule is added to the Payment Systems Law, as recommended later in this report, the above legal opinions may be desirable but not essential.

c) Rules on collateral arrangements in the context of intraday credit

Article 16 of the Payment Systems Law empowers the BOI to extend intraday credit to a participant in a designated controlled system, that may be secured by (a) a pledge over securities or (b) a pledge over cash accounts in respect of which the BOI is granted a right of set-off. Pledges over securities in the context of intraday credit benefit of the specific rules contained in Article 37 of the BOI Law, 2010, inter alia, that enables the $\mathrm{BO}$ to enforce immediately its rights, without the need to give prior notice, in deviation from the Pledge Law 5727-1967.

The BOI Law, 2010

The BOI Law 2010 provides that a goal of the Bank is to "support the stability and the 
orderly activity of the financial system"; and a function of the Bank is to "regulate the payments system and settlement systems in the economy, with the goal of ensuring their efficiency and stability, including in accordance with the Payment Systems Law."

Article 37 of the BOI Law-that is aligned with Article 16 of the Payment Systems law-also strengthens the validity, enforcement and enforceability of collateral arrangements created for the benefit of the BOI in respect of securities. Specifically, under Article 37 of the BOI Law, pledges over securities created in connection with any credit extended by the $\mathrm{BO}$, including intraday credit, shall be valid and enforceable and shall, more specifically, be regarded as a fixed lien and be given priority over pledges in favor of third parties provided that the securities are registered in favor of the Bank with a Financial Agent as defined in Section 50A of the Securities Law. The BOI may enforce such pledge, without prior notice, if a delay in the enforcement of the BOl's right would significantly impair its ability to enforce its rights. The Bank must, however, serve a notice to its debtor (or any other prejudiced party) after the enforcement of its rights. Note that in addition to the protections afforded to collateral pledged to the BOI for the purposes of intraday liquidity in Zahav as against liquidation or other order, the BOI has the right to offset cash deposited with it against participants' liabilities.

There are further agreements between the $\mathrm{BOI}$ and the banks participating in the system with regard to encumbrance and guaranteed bonds which provide collateral to the $\mathrm{BOI}$. The BOI provides intraday credit to the participants in the Zahav system against various types of collateral, including, among others, securities deposited in the BOI account at the Tel Aviv Stock Exchange Clearinghouse Ltd, cash in shekel and foreign currency on deposit at the $\mathrm{BOI}$ and certain foreign securities. The arrangements for delivering securities to the BOl's account in TASE-CH, for TASE$\mathrm{CH}$ to inform the central bank and for the central bank to provide credit in Zahav is covered by the bespoke Intraday Credit System (ICS) system which is in turn the subject of an Agreement between the parties. The agreement deals with a variety of issues including, more specifically, the operational side of the ICS system (such as the procedure for the depositing of collateral by participants in the $\mathrm{BOI}$ account at the Clearinghouse and the procedure for withdrawing collateral with the approval of the $\mathrm{BOI})$, as well as the mutual rights and obligations of the parties .

\section{The Securities Law}

With a view to ensuring the stability of the clearing houses, Article $50 \mathrm{~A}$ of the Securities Law establishes the following protective mechanisms.

Firstly, under Article $50 \mathrm{~A}$ (b) (1), a stock exchange member who buys securities that are cleared through a clearing house on the stock exchange shall not be entitled to the securities that were purchased unless the full consideration for them has been received by the clearing house. Under Article 50 A (b) (2) if the full consideration has not been received, the ownership of the securities shall be conferred upon the clearing house.

Secondly, under Article $50 \mathrm{~A}$ (c), a stock exchange member who sells securities that are cleared through a clearing house on the stock exchange will not be entitled to the 


\begin{tabular}{|c|c|}
\hline & $\begin{array}{l}\text { consideration that was received for the sale thereof, unless the stock exchange } \\
\text { member transfers the securities that were sold as stated above to the clearing } \\
\text { houses. } \\
\text { The above-mentioned provisions shall apply mutatis mutandis to a transfer of } \\
\text { securities cleared through a clearing house in the context of sale and buy back } \\
\text { transactions as well as repo transactions. } \\
\text { Thirdly, pledge of securities that serves as collateral for a clearing house member's } \\
\text { obligation to the clearing house will be valid and enforceable vis-à-vis all, even upon } \\
\text { issuance of a liquidation order, and shall be regarded as a senior fixed lien if properly } \\
\text { registered with the appropriate intermediary (be it the clearing house itself, a } \\
\text { nominee company of another financial agent that has taken specific commitments in } \\
\text { respect of the underlying securities. In addition, the clearing house may enforce } \\
\text { such pledge without prior notification to the debtor or any other prejudiced third party. } \\
\text { By means of an indirect amendment to Article } 50 \text { C of the Securities Law in the } \\
\text { Payment Systems Law, the ISA is also given responsibility for overseeing the } \\
\text { payment system embedded in the Stock Exchange Clearing House according to } \\
\text { principles which reflect those in the Payment Systems Law. There is a MoU between } \\
\text { the BOI and the ISA covering co-ordination between them. } \\
\text { Although the payment system embedded in TASE cannot benefit from the } \\
\text { protections in paras } 14 \text { and } 15 \text { of the Law concerning finality and the operation of } \\
\text { insolvency law, by virtue of its exclusion from the scope of the Payment Systems } \\
\text { Law in para } 2 \text { (a), it is nevertheless protected by Article } 50 \text { A (b) (2), as securities will } \\
\text { remain the ownership of the clearing house as long as the latter has not received the } \\
\text { full consideration for such securities. } \\
\text { The Stock Exchange Clearinghouses Ltd., which includes the Stock Exchange } \\
\text { Clearinghouse and the Maof Clearinghouse, operates as the Central Counterparty } \\
\text { (CCP). }\end{array}$ \\
\hline Assessment & Partly Observed \\
\hline C & $\begin{array}{l}\text { In its current drafting, the legal framework governing the Israeli Payment System } \\
\text { encompasses most of the building blocks necessary in order to meet the requirement } \\
\text { of legal soundness. Nevertheless, some steps might be taken to widen its scope in } \\
\text { order to cover the full range of issues needed to it fully robust } \\
\text { The areas in which enhancements could be sought are: } \\
\text { Oversight } \\
\text { The BOI would be most appropriately entrusted with the general regulatory power, } \\
\text { rather than the Ministry of Finance as currently provided for under Article } 21 \text { of the } \\
\text { Payment System Law. However, entrusting such power to the central bank is not } \\
\text { possible under the constitutional system in Israel - in Israel the implementation of } \\
\text { laws of parliament is always entrusted to the relevant Minister. The BOI is } \\
\text { responsible for the oversight of controlled payment systems according to Article } 9 \text { of } \\
\text { the Payment Systems Law whereas the Minister of Finance, in accordance with the } \\
\text { system in Israel, is entrusted with issuing regulation in general in any matter that is }\end{array}$ \\
\hline
\end{tabular}


not specifically covered be the law.

Legal protection of finality and irrevocability

The legal protection of Article 15 of the Payment Systems Law is specified in relation only to "liquidation orders." As currently drafted, the Payment Systems Law only captures the issuance of "liquidation orders" against domestic participants to the designated controlled systems. As one participant is the branch of an overseas bank and another is CLS, the international payment settlement system, the definition of "liquidation orders" would appropriately be widened in order to capture, more generally, any collective measure provided for in the Israeli Law or a third country, either to wind up to participant or to reorganize it, where such measures involves the suspending of, or imposing, limitations on, transfers or payments.

Regarding the participation of foreign participants, specific imperative rules would appropriately be enacted to capture the legal risks associated with the possible implementation of foreign laws, especially if the latter do not provide for the same level of protection of Payment Systems.

In this perspective, we would recommend the addition of a private international law rule, with a view to ensuring that 'in the event of any collective measure being taken against a participant in a (domestic) system, the rights and obligations arising from, or in connection with, the participation of that participant shall be determined by the law governing that system'.

In addition, in order to ensure the swift transmission of information as regards the taking of any such collective measure against a foreign participant connected to a (domestic) system, it would be most advisable to establish a mechanism of crossborder cooperation with corresponding foreign authorities (such as a memorandum of understanding).

We would also recommend to systematically require, upon connection of a foreign participant, a legal opinion on the foreign law governing such participant, in order to identify any legal provision under such foreign law that may negatively impact on the (domestic) system, although a private international law rule, if added to the Payment Systems Law, may be sufficient to prevent the abovementioned legal risk.

We would suggest that the wording of Article 15 of the Payment Systems Law be reviewed in the light of the system's rules defining the moment of finality (that usually coincides with the crediting/debiting of the accounts), in order to clarify the cases where a transfer order entered into a system prior to the liquidation order may be carried out by the system after such liquidation order and despite the knowledge that such system's operator has of the liquidation order. In the current drafting of this provision, it is unclear to us whether a transfer order may be validly carried out after the issuance of a liquidation order, as Article 15(d) (2) requires that 'full payment for the purpose of executing the payment order has been transferred to the credit of the system operator or to the credit of the other participant before the granting of the liquidation order'. Unless the system's operator would have, based on Article 15(c) some flexibility to determine the point in time where the granting of the liquidation order develops its effects vis-à-vis itself, in which case this should be made clearer. 
Protections are granted to the cash leg of multilateral payments of the Masav and paper-based clearing house when these payments are settled in Zahav, regardless of whether the systems have or have not been declared "controlled systems," after netting of transfer orders. The securities leg and operations before (gross) transfer orders before submission to Zahav are not so protected. The authorities are encouraged to complete their considerations concerning the type of declaration in respect of Masav and $\mathrm{BCH}$ as, until they are protected by the Law, they remain a potential source of risk for Zahav. Given the values settled, and the fact that Masav acts as an alternative means of settling payments if Zahav is unavailable, they would benefit from designation.

If it is the case that when in a contingency, payments put through the General Ledger might not be protected by paras 14 and 15 of the Payment Systems Law, this could be addressed. However, it is recognized that the General ledger is a reserve back-up system, and uses an old architecture that would need to be changed substantially in order to achieve finality. The balance of costs and benefits of such a restructuring would be worth investigating.

It would be useful to make explicit the equivalent protection available to TASE-CH in respect of its multilateral net settlement by changing paragraph 2 (a) of the Payment Systems Law.

Legal framework governing collateral arrangements

The Israeli Legislator has followed a very restrictive approach in respect of collateral arrangements, as it has deviated from the common rules contained in the Pledge Law only when collateral arrangements are created for the benefit of the $\mathrm{BO}$ and system's operators.

Hence, collateral arrangements entered into between financial institutions (including on the interbank markets) remain governed by the common law rules. As a consequence thereof, such arrangements may become null and void upon issuance of liquidation order on the basis of the claw-back rules contained in Article 268 of the Company Ordinance. In addition, the creditor must also notify its debtor of its intention to enforce its pledge, prior to enforcing effectively its rights.

This represents a serious threat to the financial stability of Israel: upon issuance of a liquidation order against a credit institution, while the system's operator and the BOI will be duly protected by the special provisions contained in the Payment Systems Law, the BOI Law and the Securities Law, all other collateral arrangements entered into with other financial institutions may be deprived of their effectiveness, thereby giving rise to a significant credit risk, including within the payment systems.

We would therefore recommend that the Israeli Legislator considers enacting a general legal framework that would capture all collateral arrangements, in general, be it in respect of cash, securities or precious metal, in the form of a pledge or a repo. Such law would facilitate the creation, enforcement and enforceability of all collateral arrangements entered into between financial institutions. In addition, such law would also appropriately contain private international law rules in respect of cross-border collateral arrangements (the cross-border element deriving from the fact that the collateral taker or collateral giver is incorporated under the laws of 
another country, or that the securities are held abroad or that the underlying securities were issued abroad). Israel might consider ratifying the Den Hague Convention on the law applicable to certain rights in respect of securities held with an intermediary (concluded on 5 July 2006) in order to swiftly solve this issue.

We consider this shortcoming to be sufficient to raise doubts about the system's ability to achieve observance within a reasonable time frame. Therefore, we have assessed the compliance with Core Principle 1 as partly observed.

CP II - The system's rules and procedures should enable participants to have a clear understanding of the system's impact on each of the financial risks they incur through participation in it.

\begin{tabular}{l|l} 
Description & The Zahav Rules deal with a wide variety of legal, business and operational issues
\end{tabular} and include all the information required for the activity of participants in the Zahav system, in both normal and emergency situations. The system rules are updated at least annually.

Following are the issues dealt with in the system rules:

General instructions:

Participation in the system:

Survey of the system structure:

Operating hours and days:

Payment orders and other messages in the system

Accounts in the system:

The settlement process for payment orders in the system:

Management of liquidity in the system, intraday credit and overnight loans:

Multilateral net settlement, including the nature of multilateral instructions, the settlement windows for multilateral payment orders, the process for redemption of a multilateral payment order, the procedure for cancelling a multilateral payment order, the procedure for extending a settlement window, the procedure for opening an emergency window for multilateral settlement, the arrangement for guaranteeing settlement and a description of the gridlock mechanism.

SWIFT services:

Information security

Administration of the system and support services:

business continuity arrangements

The procedure for introducing commercial and operational changes in the system, oversight of the introduction of changes in the system and changes in the systems located with the participants.

The determination of fees to be collected by the BOI from the system participants and the manner of their collection.

The composition of the National Payments Council and its functions and authority and the frequency of its meetings.

Resolution of disagreements:

Force majeure, responsibility limitation and suspending the applicability of the rules.

The rules of the system include a variety of appendixes which constitute an integral part of the rules. The appendixes cover 
General conditions

Details of the participants

Conditions for participation in the system

Information required for the day-to-day operation of the system, including information on the system's days and hours of operation in routine times and in special periods

Message formats

Account structures

Conditions for the provision of intraday credit and overnight loans

the hours for multilateral settlement windows and detailed rules regarding multilateral settlement and the principles and rules of the Masav and $\mathrm{BCH}$ Loss Sharing Arrangement (LSA)

general and mandatory requirements related to the SWIFT configuration and the structure of messages and recommendations for the use of SWIFT.

a description of the BOl's methods of communication between it and the system participants and ways for the participants to contact the BOI.

Business continuity plan which covers

Contact details

Use of the Situation Room at the BOI by Zahav

system participants in an emergency situation.

The services for sending payment orders during an emergency

The procedure for transferring to an alternative settlement process in

the event the Zahav system is not operational, namely Masav and the Bank's General Ledger, in which situation the settlement of payment orders will not be carried out immediately and in real time but only at the end of the day

Procedure for coordinating between the Zahav system operator and

CLS

A list of the existing fees for use of the system.

In addition to the Rules and Procedures there is a User Manual for Participants, a document containing detailed information on the operational and technical requirements. The $\mathrm{BOI}$ is required to consult with the system participants prior to making changes in the rules. In addition, the $\mathrm{BO}$ sends various circulars to system participants. These circulars detail the new instructions in various issues connected with the Zahav system. Apart from information on the system's days and hours of operation, the rules provide additional information relevant to participants, which includes, among other things, the determination of the time that a payment order enters the system, the authority to change the system's hours of activity in normal times, ad hoc changes in hours of activity and the conditions and procedure for a participant to request a change in the hours of activity (such as extending a cut-off or the time for closing a multilateral settlement window).

The Zahav system provides participants with real time information on their situation, which can assist them in controlling the financial risk they are exposed to. A system participant can view the liquidity situation in his account in real time and receive up-todate information on the status of the payment orders connected to his account. It should be mentioned that a system participant is able to access information on payment orders that will lead to the debiting of his account but not those that will lead to the crediting of his account. In addition, the Control Room of the Zahav system at the BOI provides support services to system participants and, among other things, 
system controllers monitor the liquidity situation of the participants and notify the representatives of a participant that is beginning to experience liquidity problems.

The system rules provide a comprehensive description of the authority granted to the $\mathrm{BO}$ as the central bank which operates the Zahav system and the rules related to the following issues, among others: a list of exceptional events that can lead to a decision to block or suspend a participant and the imposition of a fine on a participant if he does not follow the system rules. In addition, the system rules, together with the agreement for participation in the system, deal with various legal issues, such as the authorization to debit an account, the limits on the responsibility of the sides to an agreement, the applicable law and force majeure.

Reports are sent to the system participants each month containing in-depth statistical information on the system's operations, including information on the volume of activity, amounts of the transactions in the system, the activity of the banks in the CLS system, the liquidity situation in the system and information on the intraday credit provided to the participants according to type of credit. In addition, the policy area of the payment systems division sends current information to system participants, including reports of Zahav committee meetings, BOI decisions regarding the system's operations, proposed issues for discussion, and proposals for reforms.

The Minutes of the National Payments Council, or a summary of them, are widely circulated but not made publicly available.

The Rules provide the $\mathrm{BOI}$, in its role as the operator of the Zahav system, with discretion in a variety of circumstances. In order to create clear rules based on clear and transparent criteria, discretion was provided to the $\mathrm{BO}$ in specific areas. It should be mentioned that in all the areas in which the BOI was given discretion in making decisions which may affect the activity of a participant in the system, it must provide the participant with reasonable prior notification in order to allow the participant to respond to the decision, except in respect of eligible collateral for intraday liquidity where the Central Bank has absolute discretion and no obligation to consult. The BOI has discretion to: establish special eligibility criteria which will apply to a candidate for participation in the system; exempt a participant from some of the criteria for acceptance as a participant in the system; suspend a participant from the system in the case of an "exceptional event" as defined in Clause 29 of the rules; block a participant from activity in the system, whether it be a full blockage (from credit and debit activity) or a partial blockage (from credit activity or from debit activity); impose a fine if various conditions are fulfilled, such as a material violation of one of the rules or the recurring non-fulfillment of multilateral settlement; make ad hoc changes in the system's hours of operation in the case that such a change may harm the normal functioning of the system; approve the request of a participant to make a temporary change in the system's hours of operation; make changes in the default schedule of the system, after discussion with system participants; set a minimum required balance for a participant's settlement account; carry out a change in the priority of a message or to remove it from the queue, in accordance with or without the request of the participant, for example where the BOI has found that an "exceptional event" is occurring or in the case that a participant's account is blocked; determine the frequency of the activation of the gridlock mechanism; implement the mechanism at its discretion at times other than those at prefixed times; decide whether a settlement 
participant is eligible for intraday credit (against collateral); decide when to realize collateral which has been provided to it against intraday credit, in the case that an "exceptional event" has occurred; and, finally, to carry out changes in the fees collected from system participants.

In any situation in which the system rules provide the $\mathrm{BO}$ with the authority to make decisions or to take action, the rules require that it provide notification to the participants of the decision or the action taken. In most cases, the rules state that notification must be given as early as possible or "within a reasonable amount of time except where urgent action is required. The $\mathrm{BO}$ is required to notify the participants of any action it carries out that may have an effect on the operation of the system in general or on the activity of a particular participant; in particular the $\mathrm{BO}$ is obligated, in accordance with the rules and the Payment Systems Law, to notify participants of the issue of a bankruptcy order against a participant in the system.

There have been no additional formal training sessions for the all the participants since the launch of the system, but there is specific training for representatives of the system participants when needed and for new entrants.

The BOI holds an annual operational meeting for the participants in the Zahav system. The goal of this meeting is to update participants on various subjects, such as updates of the system rules and changes introduced into the Zahav system. During the meeting, the $\mathrm{BOI}$ also presents various issues related to the operation of the Zahav system, which include, among others, planned changes that will have an effect on the operation of the system and information on future reforms to be carried out in the payment systems. The BOI invites representatives of various departments in the $\mathrm{BO}$ to the annual meeting in order for them to present issues related to the operation of the Zahav system. In addition, time is allocated during the meeting for the representatives of the system participants to raise operational or business issues.

As part of the acceptance process of a new participant in the system, the participant is required to carry out a number of simulations on the system, in order to ensure that he is able to work with the system and that his representatives have the level of knowledge needed to use the system. The BOI also sends system participants to an annual practice session to carry out simulations for both normal and emergency situations.

A participant is permitted to change the order of settlement of the payments he has sent to the system if they are queues and as long as they have not yet been settled. In addition, a participant can cancel an order with an error in it up to the point of irrevocability (which, as the system works very fast, is to all intents and purposes also the point of finality). The payment systems that participate in the system, which send settlement results to the system after netting, are allowed to cancel a multilateral payment order as long as settlement has not yet occurred. In the event of an error in a payment order or a failure of one of the participants in multilateral settlement, the payment system is permitted to cancel the payment order, including, for example, the correction of the amount of the debit or removal of a failing participant from multilateral settlement.

The BOI has recently been working to create a mechanism which will allow an 


\begin{tabular}{|l|l|}
\hline & $\begin{array}{l}\text { amendment to the multilateral net settlement amounts to be made without releasing } \\
\text { funds already reserved in the system for such settlement. }\end{array}$ \\
\hline Assessment & Observed \\
\hline Comments & $\begin{array}{l}\text { The rules of the Zahav system and the appendixes and ancillary documents are clear, } \\
\text { complete and up-to-date and cover the full range of issues, including legal, } \\
\text { operational and business issues. The information is clear and accessible to } \\
\text { participants. }\end{array}$ \\
\hline
\end{tabular}

CP III - The system should have clearly defined procedures for the management of credit risks and liquidity risks, which specify the respective responsibilities of the system operator and the participants and which provide appropriate incentives to manage and contain those risks.

Description $\quad$ Settlement in Zahav is RTGS, with finality at the point of debit and credits-which are locked together-across payer's and receiver's settlement account in Zahav. In all circumstances, participants incur no credit (or liquidity) risk in the system. Settlement is final and subject to legal protection against the operation of insolvency laws.

Participants' deposits with the BOI, of which currently there is some NIS 100 billion system-wide, may be used as intraday liquidity for RTGS payments, making the system significantly liquid. In addition, participants have access to intraday liquidity from the BOI, subject to the delivery and pledge of securities to the BOl's dedicated account in TASE-CH. Upon delivery a message is sent to the Bank and a credit placed to a participants' sub account in Zahav which reflects the category of collateral delivered, the balance on which is then taken into account in deciding the total liquidity the participant has for payments. There has been a widening recently in eligible collateral to include foreign currency deposits at the BOI with a suitable haircut and certain securities held in Euroclear. The full list of eligible collateral is appended to the Rules.

Assets held to meet the prudential liquidity requirements set by the Banking Supervisor (see discussion of liquidity requirements in the assessment of observance of the Basel Core Principles for Effective Banking Supervision) and eligible for the generation of RTGS intraday credit may be used to generate intraday liquidity for payment system purposes. The supervisors have no extra liquidity requirement related to likely idiosyncratic liquidity demands arising from membership of payment and settlement systems.

To further protect settlement from liquidity shortages three further mechanisms exist. There is a gridlock resolving mechanism which is run automatically every 10 minutes and can be run at other times if needed. Special accounts exist in Zahav to which is transferred a participants' multilateral net settlement obligation ahead of the settlement window for the multilateral net settlement and which can be used only for that purpose. In respect of Masav and $\mathrm{BCH}$, there exist "Loss Sharing" Agreements, which can be invoked to ensure adequate funds for the multilateral net settlements. It is not, however, a true loss sharing agreement as it may not be used in the event of (or even the likelihood) a default of members. The Agreements are in the form of a guarantee which is signed as part of the Zahav membership rules, including the BOI as participant. There are emergency provisions to deal with a situation where the agreement does not fully cover a member's liability (the agreement is based on a contribution by way of guarantee based on historic values for their multilateral net obligations and so may not cover a peak not previously encountered). 
An agreement is also being put in place to enable TASE-CH's Risk Fund to be mobilized quickly in the event of problems with a member unable to meet its multilateral net cash settlement obligation in circumstances in which the Fund is able to be used. From the point of view of Zahav stability, this is a comfort and it would be desirable for the agreement to be signed as soon as possible.

It is observed that since pledged assets can by law be sold only to a party other than the pledge, in this case TASE-CH, the Bank has little option but to purchase the assets from the Risk Fund contributors outright thereby assuming a risk position, which may not be ideal from the Bank's point of view. Alternatives are for the Agreement to provide that any loss incurred by the Bank when closing out its position in the assets purchased is to be met by the members of TASE-CH; or for a panel of members to be the purchasers of the Risk Fund assets, with a similar loss sharing clause.

To avoid any disruption to CLS settlement, the three banks chosen as CLS NIS liquidity providers have each entered into an agreement (currently only in Hebrew) with the BOI for up to NIS 1 billion in emergency liquidity, to be provided against "Tier 2" capital.

In addition, participants have the ability to queue and to prioritize payments and to cancel or amend them up to the point of irrevocability which to all intents and purposes coincides with that of finality. And the BOI has the right to impose different charges for payments at different times of the day in the event of structural payment peaks emerging, to encourage submission of non-essential payments ate a different time. Furthermore, the BOI has worked to identify with participants the sorts of situations in which liquidity in the system might be stressed and agreed the most likely immediate response. And it can see in the system if a participant is developing problems, for example where the settlement account has become inactive, which could signal technical problems. Participants spoken to indicate that they have credit modules in place which allows the release of a customer payment into Zahav only if the client has adequate credit/balance.

Inability to repay intraday credit leads to the generation of an overnight loan at penal rates.

Most RTGSs, especially where there are a small number of participants handling a large volume and value of payments, as is the case in Israel, can run on system liquidity equal to around some 10 percent of the total value passing through the system. The Rules provide the $\mathrm{BOI}$ the capacity to require banks to make a certain portion of the value of their days' payments by certain times in the day to ensure a steady throughput during the day, to avoid "bunching" toward the end of day.

At present, the system is very long of liquidity, and as a result participants we spoke to were unaware of the automatic use of the gridlock mechanism every 10 minutes. In 2009 and 2010, for example, only 8 payments ended up queuing due to lack of liquidity in the participants' account, compared with 68 in 2008 when system liquidity was very much shorter. Nor have there been any occasions since the start of Zahav that multilateral net settlement has had to be delayed due to a lack of liquidity. One 


\begin{tabular}{|c|c|}
\hline & $\begin{array}{l}\text { result is the virtual non-existence of an interbank market, whether via secured via } \\
\text { repo or otherwise (though a repo master agreement is in place) which can play a } \\
\text { critical role in recycling limited liquidity during a day, especially now that settlement in } \\
\text { Zahav can take place shortly after the trades are struck. } \\
\text { Most participants will have internal systems which measure the bilateral net of their } \\
\text { payments and receipts to other participants. }{ }^{5} \text { And they may use these to prevent "free } \\
\text { riding" in which a participant deliberately maintains its net receipts to a low, or even } \\
\text { zero or negative, level, so as to minimize the use of its own liquidity. While from an } \\
\text { operational point of view, it is desirable that participants can stop sending payments to } \\
\text { a participant who, for example, can receive but cannot send payments due to } \\
\text { technical constraints, so as to prevent the second participant from becoming a } \\
\text { liquidity "sink" in times of stress, it is not always obvious what is causing the inability } \\
\text { to send payments. } \\
\text { It should be noted that there is a loss sharing arrangement (LSA) to deal with failure } \\
\text { situations in multilateral clearing of the Masav (ACH) and paper-based clearing house } \\
\text { (BCH). The details of the arrangement, the criteria for its operation, and the } \\
\text { procedures for its operation are detailed in Annexure } 8(3) \text { to the Zahav System } \\
\text { regulations. The arrangement applies to all participants who are parties to a } \\
\text { multilateral payment instruction that the payment systems-ACH and BCH-send to } \\
\text { Zahav. The purpose of the arrangement is to assure settlement finality in the event of } \\
\text { a failure on the part of one or more of the participants in the multilateral (net) } \\
\text { settlement of the payment systems, but the arrangement is not meant for situations of } \\
\text { known or nearly certain bankruptcy. In mid-2011, the BOI began, together with } \\
\text { representatives of the commercial banks, a review of the LSA features, both from the } \\
\text { perspective of increasing the amount of collateral given in the arrangement, as well as } \\
\text { from the perspective of the structure and features of the arrangement }\end{array}$ \\
\hline Assessment & Broadly observed \\
\hline Comments & $\begin{array}{l}\text { The system is currently awash with liquidity. As a result, there is little need for banks } \\
\text { to use each other to manage their liquidity and the development of a, for example } \\
\text { secured, interbank market may take some time just when it is needed at some point in } \\
\text { the future when liquidity is less plentiful. } \\
\text { Some modeling of the minimum amount of liquidity needed to enable all payments in } \\
\text { Zahav to settle in a day would help identify a possible requirement for 'start up' } \\
\text { liquidity to be placed on participants, again against the day of tighter liquidity } \\
\text { conditions. } \\
\text { The BOI might review the basis on which it provides emergency liquidity assistance } \\
\text { (ELA) to elements of the payment system, normally against outright purchase of } \\
\text { pledged assets to ensure risk is borne in the right quarter, as part of a general review } \\
\text { of it ELA arrangements (see the accompanying Financial System Stability } \\
\text { Assessment). }\end{array}$ \\
\hline
\end{tabular}

${ }^{5}$ A net send limit prevents a drain of liquidity to another participant; a net receive limit prevents a system drain to oneself, if for example one has sending problems but can continue to receive payments, and so cannot recycle liquidity into the system. 
Members of Masav and Paper Based Clearing should be encouraged to contribute collateral ex ante according to some measure of the risk they bring to the system, under a pledge protected by either or all of the Payments Systems, Securities or BOI Laws. In the case of Masav, if the members pledged assets to Masav, which might be preferable given its private sector ownership, the BOI might enter into an agreement. If it is pledged to the $\mathrm{BO}$, as it will be in the case of Paper Clearing which is owned by $\mathrm{BOI}$, lending can be provided against the pledged assets. It is for consideration whether the BOl's contribution to a loss sharing default fund should be anything other than zero.

The Bank Supervisor may wish to consider the size and management of intraday credit limits offered by direct participants to their customers, to ensure they neither act as a constraint on the smooth flow of payments to the system nor represent a source of instability by being too generous. Any regulations or guidance in this area would have to be integrated with the overall prudential regulation of bank liquidity.

The system itself does not provide facilities, such as 'stop send' or stop receive' limits, which participants can set to preserve their or the system's liquidity. But banks appear to have such mechanisms in-house; the $\mathrm{BOI}$ has intentionally left to participants the management of payment status among themselves. It is worth understanding their use, perhaps via the Zahav operations committee, to ensure they cannot be a source of instability.

CP IV - The system should provide prompt final settlement on the day of value, preferably during the day and at a minimum at the end of the day.

Description $\mid$ Zahav is an RTGS system, with finality protected by Law. Operating hours are long. Any unsettled payment orders sitting in the system at the close are cancelled and have to be resubmitted the following day. Participants may alter priority or cancel a payment awaiting settlement in the system up to the point of irrevocability, which to all intents and purposes is also the point of finality. Receivers are unaware of the incoming payment until the funds have been credited to their account, which is thus immediately following the point of finality. The system provides final settlement on the day of value, even in contingency mode.

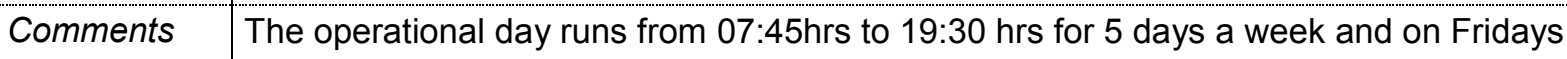
and holiday eves at 14:30. This is not unusual and was a response to banks requesting a later window to cater for evening opening which they do on three days a week. However, apart from the second Masav settlement window (which settles with same day value payments input by non-bank participants), the volumes and values settling in Zahav are low after 16:30, with around 6 percent by volumes and 7 percent by value passing through the system after this time. The longer a system is open, the longer the time is for it to go wrong and the less the time to resolve the problems.

CP V - A system in which multilateral netting takes place should, at a minimum, be capable of ensuring the timely completion of daily settlements in the event of an inability to settle by the participant with the largest single settlement obligation.

\begin{tabular}{l|l} 
Description & Does not apply \\
\hline Assessment & Not relevant \\
\hline
\end{tabular}




\begin{tabular}{|l|l|}
\hline Comments & \\
\hline CP VI - Assets used for settlement should preferably be a claim on the centr \\
other assets are used, they should carry little or no credit risk and little or no
\end{tabular}

The UIS carries out ongoing analyses of technological "cyber" risks to Zahav and in respect of other threats in the region. These include a variety of "penetration" tests.

A comprehensive survey of risk across the $\mathrm{BO}$ was commissioned from Ernst and Young and this now forms the Bank's Risk Register. Some of the risks identified related to Zahav. Two risks were considered high: the lack of an efficient system for the management of malfunctions in the system and the lack of oversight over the payment and settlement systems, including the Zahav system. Three risks were considered intermediate: the non-implementation of a full working day test at the backup site in the production environment, the lack of a solution for the operation of the system in a scenario of no access to the Control Room at the main site and nonimplementation of the pricing policy decided upon by the BOI (leading to a gap between forecasted and actual revenues).

These risks have been addressed, except for a full business contingency test and the issues surrounding cost recovery. Furthermore, payment system oversight is still in its infancy.

Zahav has a "warm" backup site some $60 \mathrm{~km}$ from Jerusalem. That is "hot" for infrastructure but "cool" for staff: operational and managerial staff has to travel to the site in the event of a move to the second site. This represents a significant source of uncertainty. A committee has been created to consider a solution to this.

Very thorough work has been done to identify every key component of the architecture, including at the participants, and to set out what the fallback is in the event a component fails. A range of Business Continuity and Disaster Recovery tests 


\begin{tabular}{|c|c|}
\hline & 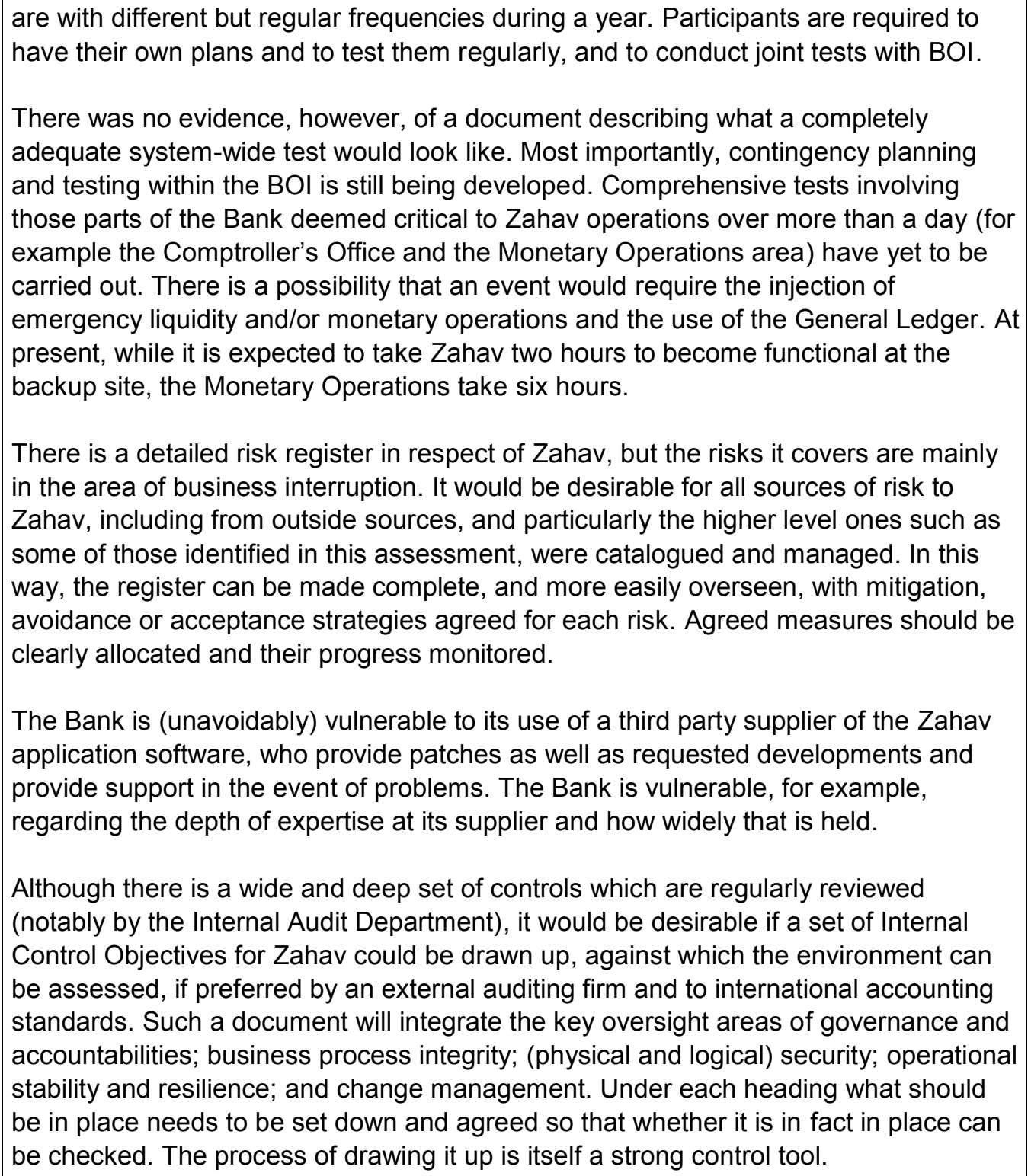 \\
\hline Assessment & Partly observed \\
\hline Comi & $\begin{array}{l}\text { The BOI has detailed and comprehensive business continuity plans for the Zahav } \\
\text { System and its related systems, which are tested regularly. However, further work is } \\
\text { required to integrate these plans and tests into an overall business continuity vision. } \\
\text { In general, high quality business continuity arrangements are a critical part of any } \\
\text { SIPS. The ability to provide ELA, to implement interest rate policy in a crisis and to } \\
\text { provide a secure means of payment are core central bank functions which should be } \\
\text { able to cater with severe and potentially prolonged events. This is especially the case } \\
\text { in Israel. An agreed overall definition of what the optimal contingency arrangements } \\
\text { should look like across all stakeholders, a ladder of increasingly demanding tests } \\
\text { capable of delivering that state, a timetable for the achievement of each rung on the } \\
\text { ladder and the allocation of the resources needed for a successful outcome should be } \\
\text { given a high priority. }\end{array}$ \\
\hline
\end{tabular}


The risks arising from the use of a third party supplier for providing and supporting the nation's core payment system application need to be monitored via the risk register, with mitigation strategies agreed and, if they cannot be found to the Bank's satisfaction, alternatives explored.

The Risk Register needs to include all risks, from within and without Zahav, which need to be proactively managed and fully integrated into overall business continuity arrangements, with clear governance on ownership of and responsibility for agreed actions to reject, reduce, or mitigate risks.

A set of Internal Control Objectives should be drawn up with a view to their ultimate assessment to international standards for systems and controls.

CP VIII - The system should provide a means of making payments, which is practical for its users and efficient for the economy.

Description $\quad$ Zahav is reliable and efficient. It provides the means for making high value payments, for the final settlement of multilateral net settlement systems, for the shekel leg of forex deals settled in CLS and for central bank and government business. Its operating day is long, to fit with bank business hours; it has several windows for multilateral net settlement; it uses standard SWIFT connectivity, providing participants with online, real time information on Zahav activity. There are a number of sources of liquidity available to its participants to enable payments to flow quickly through the system, via monetary operations and intraday liquidity provisions against a wide range of eligible collateral, including foreign currency balances at the central bank and securities held in Euroclear, the International CSD. The system is secure and has a range of responses to emergency operational situations arising from a range of potential events, including facilities in the central bank to help participants carry on their payments. The current level of liquidity is such that there are very few delays, if any, in the settlement of payments once they have been input to the system.

Like all high value payment systems, the characteristics required of them in all dimensions (liquidity, security, disaster recovery, speed, visibility, controls and so on) come at a cost. Current estimates are that the running costs alone are some NIS $8 \mathrm{mn}$ per annum. If amortization of investment is also included, the figure could well be a third higher, depending on the periods over which the amortization is allowed. Coupled to this are the costs incurred by the participants in developing suitable software, hardware and staffing and contingency arrangements, which they have to recover from their customers.

In the case of Zahav, the decision was taken not to pass on the costs of amortization to the participants but only the running costs. This is a not uncommon decision in respect of the initial investment. Whether it should continue to apply for future investments is a matter for debate with the participants. If such costs are passed on, then there will need to be agreements on what any new participants may have to contribute to earlier investment and what exiting participants have to contribute for some period into the future.

Volumes in the system have proven to be far less than the initial cost benefit analysis suggested: an expected 4,000 transactions per day in the start-up year, rising to 10,000 per day over a number of years. As of 2010 , an average of 757 transactions is 


\begin{tabular}{|c|c|}
\hline & $\begin{array}{l}\text { settled during each business day. Some of this is due to the accession of CLS leading } \\
\text { to the aggregation of deals into single amounts, where previously they had been } \\
\text { separately settled. To try to improve the use of the system, it was agreed, with the } \\
\text { National Payment Council's endorsement, to promote the system through a public } \\
\text { awareness campaign and to a lowering to NIS } 1 \text { mn of the limit on the largest value } \\
\text { which may be paid through Masav. (There is no upper limit on the value of a payment } \\
\text { in Paper Based Clearing, which can be used for significant values, for example in } \\
\text { respect of tax liabilities; and payments in excess of NIS } 1 \text { mn in Masav, if they are } \\
\text { part of a batch of payments submitted together, may be made as it requires significant } \\
\text { re-engineering of the system to exclude them). There is no lower limit on payment } \\
\text { values in Zahav: } 29 \text { percent by number and } 3 \text { percent by value of all interbank } \\
\text { payments-i.e., excluding multilateral net settlement, CLS and central bank payments } \\
- \text { is accounted for payments of less than NIS } 1 / 4 \text { million. } \\
\text { It was also agreed that in respect of those banks which significantly reduced their } \\
\text { charges, from around as much as NIS } 100 \text { to NIS } 40 \text { per payment, would be } \\
\text { exempted from Zahav charges until } 2013 \text { when the position would be reviewed }{ }^{6} \text {. } \\
\text { Even if, for strategic reasons to encourage the widest usage of this safe means of } \\
\text { payment in the economy, non-recovery of costs from some or all participants is } \\
\text { deemed appropriate, it is important that the central bank knows as accurately as } \\
\text { possible the size of its total subsidy, both in terms of sunk investment costs and a } \\
\text { charge for future investments (to avoid sudden changes in the "tariffable" amount and } \\
\text { annual running costs). } \\
\text { One important reason for an accurate measure of the true overall cost of the system } \\
\text { being identified, is to ensure the system is managed and operated as efficiently as } \\
\text { possible, with a program for cost reductions wherever possible and a tough view } \\
\text { taken on future investment, for example in hardware renewal and alternative } \\
\text { settlement in the event of a problem with Zahav. }\end{array}$ \\
\hline Assessment & Broadly observed \\
\hline Comments & $\begin{array}{l}\text { The central bank is encouraged to continue with the identification of all dedicated and } \\
\text { shared costs of Zahav, to facilitate the review of the policy for the present not to } \\
\text { recover any costs from some participants. This will enable investment decisions to be } \\
\text { made in full knowledge of their financial impact and ensure the most efficient running } \\
\text { of the system, balancing the needs of both the benefits to the wider economy, the } \\
\text { participants, and the central bank as user, owner and operator. }\end{array}$ \\
\hline \multicolumn{2}{|c|}{$\begin{array}{l}\text { CP IX - The system should have objective and publicly disclosed criteria for participation, } \\
\text { which permit fair and open access. }\end{array}$} \\
\hline Description & $\begin{array}{l}\text { Any financial sector institution as defined in the BOI Law is eligible for Zahav } \\
\text { membership and not just those who make and receive payments. This has been used } \\
\text { to enable TASE-CH to open an account to facilitate emergency procedures, for } \\
\text { example, should collateral pledged to it need to be realized. Certain exemptions have } \\
\text { been provided to CLS to enable its special requirements to be accommodated. The } \\
\text { Rules set out the eligibility criteria and are available to enquiries from potential }\end{array}$ \\
\hline
\end{tabular}

${ }^{6}$ There are no annual fixed charges, only per item charges. 


\begin{tabular}{|c|c|}
\hline & $\begin{array}{l}\text { members but not made generally available for confidentiality reasons concerning } \\
\text { some of the other parts of the Rules. Direct membership is either on- or off-line. } \\
\text { Offline members submit payments via online members, but can monitor and control } \\
\text { their activity. } \\
\text { The system rules determine the conditions of eligibility for participation in the system. } \\
\text { This includes the fulfillment of the system's working rules or procedures, the } \\
\text { technological requirements for working with the system, Swift's requirements and the } \\
\text { requirements related to security. The BOI has the discretion to determine special } \\
\text { conditions of eligibility for a particular participant. It is worth mentioning that the } \\
\text { system rules do not include eligibility criteria related to the candidate's liquidity, equity } \\
\text { or credit situation. In addition, the system rules exhaustively define the administrative } \\
\text { procedure for accepting a participant in the system, which includes various checks } \\
\text { performed for acceptance to the system, the submission of the appropriate forms and } \\
\text { the signing of a participation agreement. Furthermore, a new participant in the system } \\
\text { is required to pay the one-time entry fee of NIS } 20,000 \text { (about } \$ 5500) \text { to the BOI. The } \\
\text { Rules provide clear mechanisms, criteria and procedures for suspending or excluding } \\
\text { a member } \\
\text { Discussions are taking place to enable Government Ministries, whose payments are } \\
\text { currently managed by the BOI in Zahav, to become direct participants. }\end{array}$ \\
\hline Ass & Obs \\
\hline Comments & $\begin{array}{l}\text { Consideration could be given to extracting the high level membership and eligibility } \\
\text { requirements in a general statement, which can be posted to the website and made } \\
\text { publicly available. } \\
\text { Membership of Zahav by nonbanks raises the question of conditions under which } \\
\text { they may receive for ELA from the BOI (The issue is addressed in the accompanying } \\
\text { Financial System Stability Assessment). }\end{array}$ \\
\hline $\begin{array}{l}C P X-\text { The } \\
\text { transparent. }\end{array}$ & and \\
\hline Des & $\begin{array}{l}\text { Zahav is owned and operated by the BOI. } \\
\text { The BOI has the authority to carry out changes in the system rules, alongside its } \\
\text { obligation to consult with the participants that are affected by the change. Prior to the } \\
\text { introduction of a change that affects the activity of a payment system participating in } \\
\text { the Zahav system, the BOI must receive the approval of that payment system. } \\
\text { Discussions of functional changes in the system, changes in the system rules and } \\
\text { reforms that have implications for the activity of the Zahav system are discussed in a } \\
\text { forum (the Zahav Committee) consisting of representatives of the BOI, the banks, the } \\
\text { Postal Bank, the Stock Exchange Clearinghouses and Masav and if necessary } \\
\text { representatives of other bodies involved in payments in Israel are invited to the } \\
\text { discussions. The Committee was created in } 2004 \text { following the decision to establish } \\
\text { an RTGS system in Israel, and meets once a month. In addition, in } 2009 \text { the National } \\
\text { Council for Payment and Settlement Systems was established, which serves as an } \\
\text { advisory body. Its goal is to improve the efficiency and stability of payment systems in } \\
\text { Israel. The members of the Council are representatives of the various bodies that } \\
\text { operate in the payment systems in Israel, including representatives of the BOI, the } \\
\text { banks, the payment systems, the credit card companies, the MOF, the Association of }\end{array}$ \\
\hline
\end{tabular}




\begin{tabular}{|c|c|}
\hline & $\begin{array}{l}\text { Banks and other relevant bodies connected to the execution of payments in Israel. } \\
\text { Stakeholders from the wider community are not represented. The proceedings of the } \\
\text { Council are made widely available but not made public. } \\
\text { From the outset, the BOI decided to bear the investment in the initial system; and the } \\
\text { members bore their own start up costs. From } 2010 \text {, a decision was taken to cease } \\
\text { charging participants, given the much lower than expected volumes in the system, } \\
\text { and to take steps to promote Zahav. This will be reviewed in } 2013 \text {. The annual } \\
\text { running costs of Zahav are some NIS 8mn; together with amortization and full } \\
\text { allocation of shared costs, the full cost of Zahav will be considerably larger. In the run } \\
\text { up to the review in } 2013 \text {, it will be important to review the total cost base and the } \\
\text { scope for charging. This might involve charging from Zahav to internal BOI users, } \\
\text { such as monetary operations and intraday liquidity provision. Some internal users, if } \\
\text { they have external users, could pass on charges levied, in whole or in part. The } \\
\text { charges levied on the multilateral net settlement systems whose final settlement } \\
\text { takes place in Zahav might be charged not on a volume basis but according to the } \\
\text { reduction in risk from which they benefit by settlement in Zahav, based on the value } \\
\text { of net settlement. A view can then be taken on what the banks could reasonably be } \\
\text { expected to support by way of a tariff and which would not discourage use of Zahav. } \\
\text { Any residual, uncovered costs would then represent the central bank subsidy in } \\
\text { providing Zahav, allowing the normal budgetary mechanisms to ensure value for } \\
\text { money for the subsidy, for example in respect of hardware or other. }\end{array}$ \\
\hline Assessment & Observed \\
\hline Comments & $\begin{array}{l}\text { As noted against CP VIII, the arrangements would be more effective, accountable } \\
\text { and transparent if the fully allocated costs were available. This would provide a } \\
\text { benchmark against which strategic decisions can be taken by all parties, for example } \\
\text { via the National Payments Council, about developments and future investments and } \\
\text { as a means of management accountability for managing costs. Sharing the } \\
\text { breakdown of costs with users, for example by staff, floor space, third party charges, } \\
\text { information technology charges and so on would provide a transparent method for an } \\
\text { effective challenge process. This would be expected by users if they were asked to } \\
\text { begin meeting a share of the costs in the future. }\end{array}$ \\
\hline
\end{tabular}

Central Bank Responsibilities in applying the CPSIPS

Responsibility A - The central bank should define clearly its payment system objectives and should disclose publicly its role and major policies with respect to systemically important payment systems.

\begin{tabular}{|l|l|l|l|}
\hline Description & $\begin{array}{l}\text { A specific payment system oversight function is in the process of being created, } \\
\text { following the decision to make declarations in respect of various payment systems } \\
\text { under the Payment Systems Law of } 2008 \text { and the new powers given to the BOI under } \\
\text { the BOI Law 2010. The project is due to finish in 2013. Any review of this function } \\
\text { would be premature and has not been conducted. }\end{array}$ \\
\hline Assessment & Not assessed \\
\hline Comments & $\begin{array}{l}\text { This critical function needs to build itself up to full strength with all possible haste as it } \\
\text { has a large amount of work to do if it is to be fully functional by 2013. In particular, its } \\
\text { location within the organization needs to be considered to enable it to be fully } \\
\text { objective about Zahav and Check Clearing, both of which systems are owned and } \\
\text { operated by the central bank itself. The creation of this function, with an appropriate }\end{array}$ \\
\hline
\end{tabular}


stature, needs to be accorded the highest priority and to be tracked at the highest levels, including via the bank-wide register of significant risks, as the Bank is on risk with effect from the coming into effect of the BOI Law Paragraph 4 (a) (5).

Responsibility B - The central bank should ensure that the systems it operates comply with the core principles.

\begin{tabular}{|l|l|}
\hline Description & $\begin{array}{l}\text { A specific payment system oversight function is in the process of being created, } \\
\text { following the decision to designate various payment systems under the Payment } \\
\text { Systems Law of } 2008 \text { and the new powers given to the BOI under the BOI Law } 2010 . \\
\text { The project is due to finish in 2013. Any review of this function would be premature } \\
\text { and has not been conducted. }\end{array}$ \\
\hline Assessment & Not assessed \\
\hline Comments &
\end{tabular}

Responsibility C - The central bank should oversee observance with the core principles by systems it does not operate and it should have the ability to carry out this oversight.

Description $\quad$ Permission is given by para 13 of the Payment Systems Act 2008 for the Governor to exempt a system from Central Bank oversight and this has been exercised in respect of CLS; and oversight of the TASE-CH multilateral net payment system has specifically been made the responsibility of the ISA by indirect changes to the Securities Act paras 50(B) and 50(C) which appear in the Payment Systems Law para 24. There exists an MOU between the BOI and the ISA covering their cooperation in this regard.

The non-fulfillment of obligations specified in the law, whether by the system operator or by the participants, constitutes non-fulfillment of a legal obligation, which is a criminal offense according to the Criminal Code. The BOI is currently seeking the amendment of the Payment Systems Law, such that it will have the authority to impose fines also on a participant in a monitored payment system if it does not provide the $\mathrm{BO}$ with requested information.

According to para 21 of the Payment Systems Law the Minister of Finance may promulgate regulations for the purpose of implementing the Law. Although the Law is reasonably specific such that any regulations which may be needed are likely to be non-controversial, it would be better if the power to issue such regulations lay with the Governor.

Assessment Not assessed

Comments

Responsibility D - The central bank, in promoting payment system safety and efficiency through the core principles, should cooperate with other central banks and with any other relevant domestic or foreign authorities.

\begin{tabular}{|l|l|}
\hline Description & \\
\hline Assessment & Not assessed \\
\hline Comments & \\
\hline
\end{tabular}


Table 3. Israel: Summary Observance of CPSS Core Principles and Central Bank Responsibilities in Applying the CPs-Zahav

\begin{tabular}{|l|c|l|}
\hline \multirow{2}{*}{ Assessment Grade } & \multicolumn{2}{|c|}{ Principles Grouped by Assessment Grade } \\
\cline { 2 - 3 } & Count & \\
\hline Observed & 5 & CP 2, 4, 6, 9, 10 \\
\hline Broadly observed & 2 & CP 3, 8 \\
\hline Partly observed & 2 & CP 1,7 \\
\hline Non-observed & & \\
\hline Not applicable & 1 & CP 5 \\
\hline Not assessed & 4 & Responsibility A- D \\
\hline
\end{tabular}

\section{RECOMMENDATIONS AND AUTHORITIES' RESPONSE}

\section{A. Recommendations}

\section{Great strides have been taken in the past decade in implementing a robust high} value settlement landscape. The challenge now is to bed down the system's risk management, operational controls, and business continuity arrangements to a challenging standard as appropriate for the Israeli context. There is a need, too, to ensure that all systemically important systems in Israel benefit from the full protection of the law, and that the net settlement systems have suitable loss sharing agreements, backed up by the means of realizing the risk fund in emergency. Work needs to be done to ensure that any subsidy for Zahav is as small as possible, via a rigorous identification and control of costs and a passing on of costs where reasonable. The high values still permitted to settle in $\mathrm{BCH}$ should be reviewed with a view to their settlement in Zahav. Finally, work needs to be done to ensure that the system can be operationally liquid in stressed circumstances, including via tools such as start of day "pump priming" and "throughput" rules, and that the banks retain their skills in managing in a tight liquidity environment. All specific recommendations below are for the BOI unless indicated otherwise.

19. The authorities need to press ahead with their plans to establish and operate an effective oversight function in keeping with the international standard in this area. Progress has already been made, and the project is due to be completed in 2013, at which point a dedicated assessment would be valuable.

\section{CP1—well founded legal basis}

- Widen the Payment System Law to cover insolvency action emanating from foreign laws; 
- Widen the Payment System Law to capture the full range of events which could have retroactive effects;

- $\quad$ Clarify the wording of Article 15 of the Payment Systems Law;

- $\quad$ Specify that the Israeli law shall govern the rights and obligations of all (domestic and foreign) participants, including upon issuance of liquidation order;

- $\quad$ Organize the cross-border communication with other authorities to be informed of the liquidation order issued in respect of foreign participants;

- $\quad$ Require a legal opinion prior to connecting any foreign participant;

- $\quad$ Establish a general legal framework capturing all financial collateral arrangements entered into between financial institutions (including private international law rules);

- $\quad$ Complete considerations concerning the type of declaration in respect of Masav and $\mathrm{BCH}$ as, until they are protected by the Law, they remain a potential source of risk for Zahav;

- Increase finality benefits from the protection of the Payment Systems Law when payments are settled in the BOI's General Ledger in a contingency situation, either by designation, or more simply, via the GL being declared a part of the Zahav Payment System in contingency situations, and consider costs and benefits of technical adjustments to the General Ledger to enable finality to be achieved; and

- $\quad$ Make explicit the equivalent protection available to TASE-CH in respect of its multilateral net settlement by changing paragraph 2 (a) of the Payment Systems Law, which would have no impact on the supervisory arrangements (BOI, ISA);

\section{CP3 - Clearly defined procedures to manage credit and liquidity risks}

- Consider what can be done to encourage banks to actively manage their liquidity, including by the use of a secured interbank market, against the day that liquidity is less plentiful;

- $\quad$ Model the minimum amount of liquidity needed to enable all payments in Zahav to settle in a day and consider imposing a 'start up' liquidity requirement on participants, again against the day of tighter liquidity conditions;

- Consider "throughput" limits to ensure a steady flow of payments throughout the day;

- Review the basis on which the BOI provides ELA to elements of the payment system, normally against outright purchase of pledged assets to ensure risk is borne in the 
right quarter, as part of a general review of it ELA policy (see the accompanying Financial System Stability Assessment).

- Review the Masav/BCH Loss Sharing Agreements and encourage collateral to be set aside ex ante according to some measure of the risk members bring to the system, under a pledge protected by either or all of the Payments Systems, Securities or BOI Laws. Consider whether the BOI's contribution to a default fund should be anything other than zero;

- $\quad$ Review prudential requirements on banks' liquidity, taking into account overall liquidity requirements and banks' intraday use of liquid assets to meet payment system requirements;

\section{CP7—high degree of security and operational stability}

- Give a high priority to agreeing definition of what the optimal contingency arrangements should look like across all stakeholders, a ladder of increasingly demanding tests capable of delivering that state, a timetable for the achievement of each rung on the ladder and the allocation of the resources needed for a successful outcome;

- $\quad$ Ensure the Risk Register includes all risks, from within and without Zahav, and is proactively managed and fully integrated into the business continuity arrangements, with clear governance on ownership of and responsibility for agreed actions to reject, reduce, or mitigate risks;

- Draw up a set of Internal Control Objectives with a view to their ultimate assessment to international standards for systems and controls;

\section{CP8 - a practical and efficient means of payment}

- $\quad$ Continue with the identification of all dedicated and shared costs of Zahav, to facilitate the review of the policy for the present not to recover any costs from users;

\section{CP9—objective and publicly disclosed criteria for participation}

- $\quad$ Consider extracting the high level membership and eligibility requirements in a general statement which can be posted to the website and made publically available;

\section{CP10 - effective, accountable and transparent governance arrangements}

- Consider sharing the breakdown of costs with users, for example by staff, floor space, third party charges, IT charges and so on to improve transparency and enable an effective challenge process; 


\section{Recommendations $A$ and $B$-define and disclose oversight objectives and policies and ensure systems central bank operates comply with core principles}

- $\quad$ Bring Oversight function up to full strength with all possible haste. Consider its location within the organization to enable it to be fully objective about Zahav and Check Clearing, both of which systems are owned and operated by the central bank itself. Accord this function the highest priority and track progress at a senior level;

\section{Table 4. Israel: Recommended Actions to Improve Observance of CPSS Core Principles and Central Bank Responsibilities in Applying the CPs- Zahav}

\begin{tabular}{|c|c|}
\hline $\begin{array}{c}\text { Reference } \\
\text { Principle/Responsibility } \\
\end{array}$ & $\begin{array}{c}\text { Recommended Action } \\
\text { (sequencing) }\end{array}$ \\
\hline \multicolumn{2}{|l|}{ Legal foundation } \\
\hline CP I - Sound legal basis & $\begin{array}{l}\text { Cover foreign law risk, all possible events with retroactive effects and the } \\
\text { full range of eligible collateral- }-24 \text { months } \\
\text { Complete declarations for Masav and } \mathrm{BCH}-6 \text { months } \\
\text { Explore strengthening of finality in General Ledger settlement }-36 \text { months } \\
\text { Make explicit the equivalent protection available to TASE-CH in respect of } \\
\text { its multilateral net settlement by changing }-24 \text { months }\end{array}$ \\
\hline \multicolumn{2}{|c|}{ Understanding and management of risks } \\
\hline $\begin{array}{l}\text { CPs II-III - Clear Rules } \\
\text { and management of risks }\end{array}$ & $\begin{array}{l}\text { Encourage readiness of interbank market-12 months } \\
\text { Model start-up liquidity in Zahav-12 months } \\
\text { Consider "throughput" limits-- } 6 \text { months } \\
\text { Review provision of BOI ELA to elements of the payment system-12 } \\
\text { months } \\
\text { Review support arrangements for TASE-CH-12 months } \\
\text { Redesign Masav/BCH Loss sharing Agreement and modalities for its } \\
\text { mobilization-12 months } \\
\text { Review prudential liquidity requirements in light of liquidity use in Zahav- } \\
12 \text { months }\end{array}$ \\
\hline \multicolumn{2}{|l|}{ Settlement } \\
\hline $\begin{array}{l}\text { CPs IV - VI Prompt } \\
\text { settlement, use of central } \\
\text { bank money }\end{array}$ & None \\
\hline \multicolumn{2}{|c|}{ Security and operational reliability, and contingency arrangements } \\
\hline $\begin{array}{l}\text { CP VII - secure, reliable, } \\
\text { adequate contingency } \\
\text { arrangements }\end{array}$ & $\begin{array}{l}\text { Define optimal arrangements, test their working-24 months } \\
\text { Integrate risk management-12-24 months } \\
\text { Draw up internal control objectives and prove them }-36 \text { months }\end{array}$ \\
\hline \multicolumn{2}{|c|}{ Efficiency and practicality of the system } \\
\hline $\begin{array}{l}\text { CP VIII - practical and } \\
\text { efficient }\end{array}$ & Review strategy on pricing and make costs transparent-24 months \\
\hline \multicolumn{2}{|l|}{ Criteria for participation } \\
\hline $\begin{array}{l}\text { CP IX - fair and open } \\
\text { access }\end{array}$ & Make eligibility criteria publically available-12 months \\
\hline
\end{tabular}




\begin{tabular}{|l|l|}
\hline $\begin{array}{c}\text { Reference } \\
\text { Principle/Responsibility }\end{array}$ & \multicolumn{1}{c|}{$\begin{array}{c}\text { Recommended Action } \\
\text { (sequencing) }\end{array}$} \\
\hline Governance of the payment system & $\begin{array}{l}\text { Build and integrate Zahav business model and ensure minimum central } \\
\text { bank subsidy-36 months }\end{array}$ \\
\hline$C P X$ & $\begin{array}{l}\text { Apply Payment Systems Law to systems for which a declaration has yet to } \\
\text { be made; get oversight fully operational, with highest priority, and suitably } \\
\text { organized; make approach, principles and objectives publicly available- } \\
\text { 12-24 months }\end{array}$ \\
\hline Responsibilities $A-D$
\end{tabular}

\section{B. Authorities' response}

20. We would like to express our appreciation to the IMF and the assessment team for their comprehensive report, and we welcome the recommendations for the Zahav (RTGS) system. The Bank of Israel (BOI) has learned from the FSAP process, and we believe that it will contribute to the stability of Israel's financial system infrastructure in general, and to the stability of the Zahav system in particular. We are in the process of establishing an oversight function that will oversee the payment and settlement systems in Israel, and expect the process to be completed in 2013. We are confident that the recommendations of the IMF will assist the oversight team in its work.

21. As part of the evaluation of the Zahav system, recommendations were also made regarding other systems, such as the Paper-based Clearing House, Masav, and the Tel Aviv Stock Exchange Clearing Houses. We will be undertaking a detailed review of these issues as well and will adopt any changes necessary.

\section{The Bank of Israel's response to the detailed recommendations follows:}

CP1: The BOI will thoroughly study all the recommendations for amending the Payment Systems Law and other legal topics. After the necessity to accept the suggested recommendations is determined, the Bank will act toward their implementation. It should be emphasized that changes of this type require long periods of time for implementation. The General Ledger system serves as the last resort in the event of an application failure in the Zahav system. This is not a near real time automated system but rather a system that works in batches at the end of the day. Furthermore it does not include all the settlement mechanisms that exist in the Israeli RTGS system. Therefore it does not ensure final settlement at the end of the batch process.

CP3: We will examine and weigh the various issues raised in the recommendations and will implement any changes as needed. Please note that the Zahav system has a variety of tools that enable participants to manage liquidity, as well as tools that allow the Bank of Israel to regulate the transactions in the system during the day, such as variable pricing over the course of the day. We will ensure that the participants will be familiar with the 
liquidity management tools that exist in the Zahav system along with the practical ways in which they can be used.

As is recommended, we will consider the size and management of intraday credit limits offered by direct participants to their customers. We will study what has been done in other countries in this area and will work to ensure that the implementation of the recommendation does not increase liquidity risk in the system.

CP7: The Bank of Israel has already begun implementing the main recommendations in this Principle.

A review and evaluation of all the controls - including, among other things, their quality, effectiveness and integration in the Zahav system - is carried out periodically by Internal Audit, in accordance with up-to-date and generally accepted standards and methodologies.

CP8: The Bank of Israel prepared a pricing module that includes all the activities of the Bank, and specifically the RTGS operation activities. The pricing module will be used as a basis for a justified pricing tariff when we change our current pricing policy.

CP9: We accept the recommendation and will work to implement it.

CP10: We accept the recommendation in principle. If, for example, we decide to collect hardware replacement costs from the participants, then we will proceed to implementing it. 